\title{
IMPLIKASI TEORI PEMBELAJARAN JEROME BRUNER DALAM NUANSA PENDIDIKAN MODERN
}

\author{
Zulfikar Ali Buto \\ STAIN Malikussaleh Lhokseumawe \\ Email: zaule_lsm@yahoo.com
}

\section{Abstrak}

Jerome S. Bruner is one of the best-known and influential psychologists of the twentieth century. He was one of the key figures in the so-called 'cognitive revolution' - but it is the field of education that his influence has been especially felt. His books The Process of Education and Towards a Theory of Instruction have been widely read and become recognized as classics, and his work on the social studies programme - Man: A Course of Study (MACOS) - in the mid-1960s is a landmark in curriculum development. More recently Bruner has come to be critical of the 'cognitive revolution' and has looked to the building of a cultural psychology that takes proper account of the historical and social context of participants. This theory need to be analise which geves some information of cognitive development of the student in teaching learning. Theory not only talk about cognitive but also affective and psychomotor. All of these aspects have been included in teaching learning process, so the teacher have to be responsible to apply these process well. Based on the statement above, the writer is interested to discuss about cognitive concept, applied in teaching-learning process in this era.

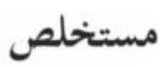

$$
\begin{aligned}
& \text { هذه المقالة باحثة عن جرومي برونر، و هو الرجلُ عالم نفساني و كان جرومي برونى مشهورا و }
\end{aligned}
$$

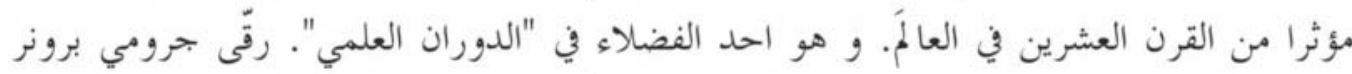

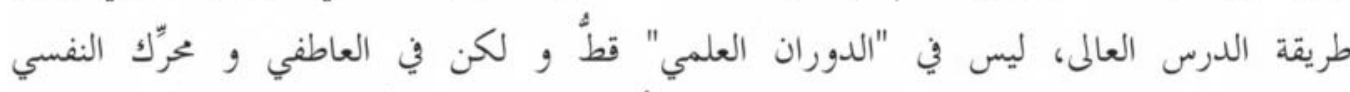

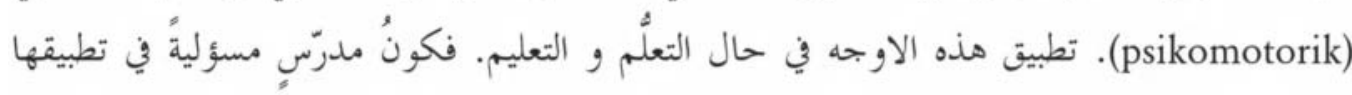

Keywords: Pembelajaran, Pendidikan Modern, Pengetahuan. 


\section{A. Pendahuluan}

Pendidikan diartikan secara sederhana sebagai usaha manusia untuk membina keperibadian sesuai dengan nilai-nilai di dalam masyarakat, kebudayaan dan agama. Berikutnya pendidikan juga diartikan sebagai usaha sadar yang dijalankan oleh seseorang atau kelompok orang lain agar menjadi dewasa atau mencapai tingkat hidup atau penghidupan yang lebih tinggi baik secara mental maupaun spiritual. ${ }^{1}$ Istilah pendidikan dewasa ini telah banyak mengalami perkembangan baik secara teoritis ataupun praktis, berbagai macam percobaan serta penelitian telah banyak melahirkan ratusan folosof pendidikan yang hanya hasilnya dijadikan dasar atau landasan operasional pendidikan di lapangan.

Menjalankan pendidikan secara garis besara tidak semudah membalikkan telapak tangan. Bermacam persoalan sering kali menjadi penghambat atau penghalang pertumbuhan pendidikan baik di daerah, pusat bahkan hingga pendidikan dunia. Persoalan yang di hadapi tidak jauh berkisar antara unsur yang terdapat dalam pendidikan itu sendiri. Unsur disebut juga dalam bahasa Arabnya dengan 'amilun - 'Awamilun artinya dasar pendidikan yang berupa, tujuan pendidikan, subjek pendidikan, objek pendidikan, materi atau kurikulum pendidikan, metode pendidikan, alat atau media pendidikan, waktu pendidikan, dan evaluasi pendidikan. ${ }^{2}$ unsur-unsur tersebut, walau semua unsur sering mengalami kendala yang signifikan akan tetapi dalam proses pembelajaran yang seringkali mengalami kendala adalah pada subjek didik dan objek didik.

Subjek didik dan objek didik adalah para murid dan guru, namun sejauh ini para murid adakalanya dijadikan sebagai peserta subjek didik dan adakalanya dijadikan sebagai objek didik, misalkan dalam proses Pembelajaran Aktif, Inovatif, Kreatif, Efektif, dan Menyenangkan (PAIKEM). Proses PAIKEM meletakkan aktifitas siswa di atas segalanya untuk mengoperasionalkan pembelajaran di kelas peranan seorang guru hanya sebatas fasilitator, modeling, dan motivator. ${ }^{3}$ Dengan mengoperasionalkan PAIKEM dalam pembelajaran tiga ranah yang menjadi fokus tujuan pendidikan ternyata memberikan dambak yang posistif, secara kognitif, afektif dan skomotorik.

1 HALabullahal, Dasar-dasar Ilmu Pendidikan (Jakarta: Raja Grapindo Persada, 2008), hal. 1

2 HALafifuddin dan Zulfikar, Ilmu Pendidikan (Diktat Ilmu Pendidikan STAIN Malikussalehal Lhalokseumawe, 2007), hal. 8

3 Oemar Malik, ProsesBelajar Mengajar (Jakarta: Bumi Aksara, 2006), hal. 56 
Proses pendidikan yang dewasa ini lahir dengan istilah pembelajaran, hal ini tentunya memberikan perhatian bersama bagi semua pengamat dan praktisi pendidikan untuk melihat ulang perjalanan pembelajaran yang selama ini berjalan. Telah banyak para ahli serta folosof pendidikan yang telah menghabiskan usia serta waktunya untuk memberikan kontribusi bagi pengembangan pendidikan hari ini, tanpa terkecuali adalah guru atau pendidik sebagai paraktisi di lapangan. Sebagaimana yang tertera di atas terlihat bahwa fenomena yang sering muncul ditengah pendidikan kita di Indonesia adalah mengenai perkembangan peserta didik dan perkembangan seorang pendidik, walau unsur yang lain juga ada namun tidak terlalu muncul dipermukaan.

Seringnya fenomena yang terjadi antara duabelah pihak antara sang guru dan sang murid, memberikan dampak negatif bagi perkembangan ranah kognitif, ranah efektifnya dan ranah psikolotoriknya. Khususnya fenomena ranah kognitif Terjadinya mis komunikasi antara murid dan guru atau sebaliknya antara guru dan murid. Kedua belah pihak memberikan peluang untuk saling menyoroti ketika para murid tidak lulus atau tidak memliki perubahan sama sekali setelah menempuh pembelajaran yang diberikan oleh pihak sekolah. Dalam hal ini kita tidak dapat menyalahkan sebelah pihak, siapa yang harus disalahkan ketika para murid tidak lulus atau tidak mengalami perubahan setelah mengikuti proses pembelajaran. Akan tetapi perlu penganalisaan yang tajam untuk menemukan solusi atau langkah yang jelas untuk memperbaiki kekurangan dan kemerosotan pendidikan hari ini.

Menjawab fenomena tersebut perlu melihat kajian teori yang nantinya memberikan pengalaman bersama untuk memecahkan permasalahan yang ada. Menurut teori perkembangan pemebelajaran bahwa sikap siswa atau peserta didik tidak hanya memerlukan respon atau stimus untuk melakukan sesuatu akan tetapi diperoleh karena pengulangan hubungan $S-R$ dan adanya reward dan reinforcement namun berupa fungsi pengalaman-pengalaman perceptual dan proses kognitif yang mencakup ingatan, retensi, lupa, pengolahan informasi, dan sebagainya. Teori ini disebut dengan teori Kognitivisme, teori ini berpendapat bahwa belajar adalah perubahan persepsi dan pemahaman. Perubahan persepsi dan pemahaman tidak selalu berbentuk perubahan tingkah laku yang diamati. ${ }^{4}$ Teori Kognitivisme telah banyak dikembangakan oleh beberapa ahli seperti teori perkembangan Piaget, teori belajar penemuan Jerome Bruner, teori belajar bermakna Ausubel, dan teori belajar

4 Abdul halamid, Teori Belajar dan Pembelajaran (Buku, tidak diterbitkan), hal. 20 
Gagne. ${ }^{5}$ Sekilas pandang teori tersebut menarik untuk dikaji sebagai pertimbangan kita dalam menjalankan proses pembelajaran, guna tercapainya tujuan atau visi dan misi pendidikan.

Fenomena yang banyak serta kongkrit di atas memberikan gambaran yang berarti bagi perkembangan pendidikan di Indonesia umumnya dan daerah kita khususnya, maka untuk mengkaji segala permasalahan dan tidak menimbulkan permasalahan baru maka pembahan ini mencoba memparkan beberapa hal dari teori Jerome Bruner, di antaranya pengertian teori belajar discovery menurut Jerome Bruner, hasil Percobaan yang dilakukan oleh Jerome Bruner dalam mengembangkan teori belajar discovery, prinsip teori belajar discovery menurut Jerome Bruner, kelemahan dan kelebihan teori belajar discovery dalam pembelajaran, dan implikasi teori belajar discovery dalam proses pemebalajaran.

\section{B. Pembahasan}

Jerome Bruner lahir pada 1 oktober 1915, ia adalah salah satu yang terkenal dan berpengaruh psikolog terbaik abad kedua puluh. Dia adalah salah satu tokoh kunci dalam yang disebut revolusi kognitifisme, eksistensinya bidang pendidikan yang telah memiliki pengaruh besar dalam proses pembelajaran. Buku-bukunya Proses Pendidikan dan Menuju Teori Instruksi telah banyak dibaca dan menjadi diakui sebagai klasik, dan karyanya pada program studi sosial Man: A Course of Study (MacOS) pada pertengahan 1960-an adalah salah satu bangunan di pengembangan kurikulum. Lebih baru Bruner telah datang untuk bersikap kritis terhadap 'revolusi kognitif' dan telah melihat ke gedung sebuah psikologi memperhitungkan budaya yang tepat dari konteks historis dan sosial peserta.

Jerome S. Bruner (1966) adalah seorang ahli psikologi perkembangan dan ahli psikologi belajar kognitif. ${ }^{6}$ Yang mengakui balajar adalah untuk mempertahankan dan mentransformasikan informasi secara aktif. Sebagai tokoh kognitivisme belajar bukanlah hanya pembentukan tingkah laku yang diperoleh karena pengulangan hubungan S-R dan adanya reward dan reinforcement tetapi merupakan fungsi pengalaman-pengalaman perceptual dan proses kognitif yang mencakup ingatan, retensi, lupa, pengolahan informasi, dan sebagainya. Dari hal. 38.

5 Yatim Riyanto, Paradigma Pembelajaran, (Jakarta: Kencana Prenada Media Group, 2009),

6 Ratna Wilis Dahalar, Teori-teori Belajar (Jakarta: Erlangga, 1989), hal. 97 
penyataan diatas disimpulkan bahwa belajar merupakan suatu kegiatan disengaja yang bertujuan mencapai suatu kecakapan, kepandaian atau kemahiran baru yang dapat digunakan dalam kehidupan, tidak seorang pun membantah bahwa sepanjang hidupnya manusia tidak akan pernah berhenti belajar, setiap menghadapi situasi baru, ia selalu mempelajarinya "agar dapat bereaksi secara baik" terhadap kondisi yang sedang dihadapinya. Dari referensi yang dirasakan kurang dalam pembehasan ini, penulis tidak banyak menemukan sejarah seluk beluk perjalanan hidup Bruner, untuk itu penulis tidak banyak memaparkan biografi sosok tokoh kognitivisme ini.

Sebagai seorang penganut kognitivisme banyak penelitiannya tentang persepsi manusia, motivasi, belajar, dan berpikir. Menurutnya memperlajari manusia berarti manusia adalah sebagai pemproses, pemikir, dan pencipta informasi. Dari sekian karyanya tentang the proses of education yang diterbitkan pada tahun 1960, merupakan rangkuman dari hasil konperensi woods hole yang diadakan pada tahun 1959, suatu konperensi yang membawa banyak pengaruh pada pendidikan umumnya, pengajaran sains khususnya. Oleh karena itu, Bruner memusatkan perhatiannya pada masalah apa yang dilakukan manusia dengan informasi yang diterimanya, dan apa yang dilakukannya sesudah memperoleh informasi yang diskrit itu untuk mencapai pemahaman yang memberikan kemampuan padanya.

Jerome S. Bruner adalah ahli psikologi perkembangan yang memiliki perhatian terhadap kemajuan pendidikan, terlihat dalam empat tema pendidikan yang selalu ia sorot demi pengembangan peserta didik sebagai berikut:

1. Struktur pengetahuan

Struktur pengetahuan dipandang penting bagi peserta didik karena akan memberi dorongan untuk melihat fakta-fakta yang kelihatannya tidak ada hubungan dapat dihubungkan antara satu dengan yang lainnya dan pada informasi yang telah dimilikinya.

2. Kesiapan (readiness) untuk belajar

Kesiapan belajar juga sangat urgen dalam pendidikan, kesiapan belajar terdiri dari penguasaan keterampilan-keterampilan yang lebih tinggi lagi.

3. Nilai Intuisi dalam Belajar

Nilai intuisi diharapkan akan dapat merumuskan teknik-teknik intelektual (belajar) untuk sampai pada formulasi-formulasi tentative tanpa melalui langkahlangkah analisis untuk mengetahui apakah fomulasi-formulasi itu merupakan kesimpulan-kesimpulan yang benar. 
4. Motivasi atau keinginan untuk Belajar ${ }^{7}$

Dengan adanya motivasi belajar diharapkan akan tertanamkan pada pengalaman-pengalaman pendidikan yang secara langsung mau berpatisifasi secara aktif dalam menghadapai proses belajar mengajar.

\section{a. Pengertian teori belajar discovery menurut Jerome Bruner.}

Banyak ahli psikologi dengan segala aliran dari masa ke masa selalu merumuskan konsep-konsep tentang belajar. Kemudian tiap aliran atau pandangan mempunyai definisi model dan konsep belajar yang berbeda. Namun sebelum sampai pada pemahaman tentang teorinya, yaitu belajar penemuan (discovery learning), kita perlu menelusuri arti penemuan (discovery). Walaupun orang dapat mengatakan bahwa balajar berarti menghasilkan suatu penemuan, kita akan memperoleh arti khusus belajar dari konsep yang diajukan Bruner. Sebagai mana tokoh terdahulunya Ahli psikologi kognitif lain seperti Piaget menyarankan bahwa anak-anak sebaiknya diberi peran aktivitas kognitif di kelas agar dapat menyokong belajarnya dalam memperoleh "penemuan"

Banyak ahli menganggap Dewey (1933) seorang pelopor aliran behavioristik mempunyai banyak andil dalam menegakkan konsep discovery learning. Dengan "learning by doing" nya, Dewey mempraktikkan analisisnya tentang "the complete art of reflective" sebab ia membuat garis besar model berfikir mulai dari hal yang membingungkan sampai pemecahannya. Mengenal discovery learning, Johnson (1979) membedakan dengan inquiry learning. Dalam discovery learning, ada pengalaman yang disebut AHA experience yang mungkin dapat diartikan seperti "Nah, ini dia". Sebaliknya inquiry tidak selalu sampai pada proses tersebut. Mengapa demikian? Hal ini karena akhir proses discovery learning adalah penemuan, sedangkan bagi inquiry learning akhirnya terletak pada kepuasaan berkegiatan meneliti. ${ }^{8}$

Secara garis besar dari beberapa pendapat di atas penulis dapat menganalisa bahwa strategi pembelajaran dan belajar penemuan sama, namun proses tujuan yang dijalani memiliki titik fokus perbedaan tersendiri terhadap apa yang dilakukan. Jika starteagi inkuiri melihat bagaimana proses cara memperolehnya agar siswa belajar untuk menyerahakan segala kemampuannya untuk berfikir, belajar penemuan

7 Ibid. hal. 98

8 Nurhalayati, Teori Belar dan Pembelajaran (Diktat: STAIN malikussalehal Lhalokseumawe, 2009), hal. 31 
lebih menitik beratkan pada apa yang meraka pikirkan atau yang mereka dapatkan untuk menambah pembendaharaan ilmu pengetahaun. Hal ini sesuai dengan definisi belajar dilihat dalam proses pembelajaran yang disampaikan oleh Bruner adalah proses memperoleh informasi baru, transformasi informasi, dan menguji relevasi dan ketepatan pengetahuan. ${ }^{9}$

Teori belajar penemuan menurut Bruner merupakan belajar untuk pengembangan kognitif peserta didik. Jika Piaget mengatakan pengembangan kognitif menyebabkan perkembangan bahasa peserta didik, sebaliknya menurut Bruner perkembangan bahasa peserta didik besar pengaruhnya terhadap perkembangan konitif. Ini sangat beralasan kerena behasa adalah alat untuk membuka cakrawala pengetahuan dunia. Menurut Bruner perkembangan konitif seseorang terjadi melalui tiga tahap yang ditentukan oleh caranya melihat kondisi lingkungan. Yang pertama tahap enaktif, yaitu tahap dimana seseorang melakukan aktivitas-aktivitas dalam usahanya memahami lingkungan, tahap ini lebih didominani pada usia anak 5 s.d 7 tahun, misalkan seorang anak secara enaktif mengetahui bagaimana mengendarai sepeda motor, yang kedua tahap ikonik yaitu tahap dimana seseorang melihat dunia melalui gambar-gambar dari visualisasi verbal, misalkan pada pengenalan konsep pira mida dll, dan yang ketiga tahap simbolik yaitu dahap dimana gagasan-gagasan abstrak banyak dipengaruhi oleh bahasa dan logika, misalkan pada pengenalan timbangan melalui permainan jungkak-jungkik ${ }^{10}$

Menurut Bruner untuk mengembangkan kognitif siswa perlu proses transformasi informasi yang benar secara bertahap, tahapan-tahapan terebut menurutnya ada tiga yaitu sebagai berikut:

1. Perolehan informasi, yaitu tahap permulaan, dimana infromasi diterima dari luar, informasi secara sederhana diartikan adalah sebagai ilmu pengetahuan.

2. Pengolahan informasi, yaitu penyesuaian informasi-informasi yang telah diperoleh berupa pengklasifikasian secara objeltif.

3. Checking atau mengadakan "test kecukupan" atau kebenaran terhadap informasi yang telah diolahnya tersebut. ${ }^{11}$

Berbagai sumber yang ada, maka teori belajar penemuan yang ditemukan oleh Bruner adalah memahami konsep, arti, dan hubungan melalui proses intuitif

9 Abdul HALamid, Teori Belajar dan Pembelajaran(Buku, Program Pascasarjana Universitas Negeri Medan, 2007), hal. 23

10 Ibid. 24

11 Ramly Mahala, Psikologi Pendidikan (Banda Acehal: Selamat Sejahaltera, 2002), hal. 21 
(yang disesuiakan dengan kemampuan masing-masing) untuk akhirnya sampai kepada sesuatu kesimpulan yang disebut dengan istilah discovery learning. Bruner menganggap bahwa belajar penemuan sesuai dengan pencarian pengetahuan secara aktif oleh pelajar, dan dengan sendirinya memberikan hasil yang paling baik. Berusaha sendiri untuk mencari pemecahan masalah, menghasilkan pengetahuan yang benar-benar bermakna bagai pembelajaran khususnya bagi peserta didik. Selain teori discovery, teori ini juga dikenal sebagai teori intruksi yang dimabil dari makna proses perolehan kognitif itu sendiri. Menurutnya suatu teori intruksi hendaknya meliputi beberapa hal berikut:

a. Pengalaman-pengalaman optimal bagi siswa untuk mau dan dapat belajar.

b. Penstrukturan pengetahuan untuk pemahaman optimal

c. Perincian urutan-urutan penyajian materi pelajaran secara optimal

d. Bentuk dan pemberian reinforsemen (hadiah dan hukuman).

Menurutnya pemberian reinforsemen (hadiah dan hukuman) harus dipikirkan, harus diberikan sesuai dengan kondisinya pada saat proses belajar mengajar. ${ }^{12}$ Dengan demikian proses pendewasaan kognitif seseorang menurut Bruner adalah sebagai berikut:

1. Pertumbuhan kognitif ditunjukkan oleh bertambahnya ketidak tergantungan respon dari stimulus.

2. Pertumbuhan kognitif tergantung pada bagaimana seseorang mengintegrasikan peristiwa-peristiwa menjadi suatu sistem simpan yang sesuai dengan lingkungan.

3. Pertumbuhan kognitif seseorang menyangkut peningkatan kemampuan untuk berkata pada dirinya sendiri atau orang lain, dengan pertolongan kata-kata dan simbul-simbul, apa yang telah dilakukannya atau akan dilakukannya.

Perkembangan kognitif seseorang sangat ditentukan oleh proses yang dijalaninya, melalui peristiwa, lingkungan, dan simbul-simbul dan berkat pertolongan kata-kata yang nantinya dapat menjadi kesimpulan pengetahuan serta dapat menambah pembendaharaan daya kognitif seseorang.

\section{b. Percobaan yang dilakukan oleh Jerome Bruner dalam mengembangkan teori belajar discovery.}

Teori yang menarik serta dapat dijadikan sebagai bahan perbandingan bagi pembaca atau orang-orang yang mempelajarinya tidak akan menjadi masalah besar, walau pada hakikatnya teori yang dihasilkannya tidak lagi relevan bagi perkembangan

12 Ratna Wilis Dahalar, Teori-teori..., hal. 106 
zaman dewasa ini. Relevansi sebuah teori dapat dijadikan sebagai perbandingan untuk mengembangkan teori berikutnya. Sedangkan hasil percobaan dari teori tersebut menjadi pengalaman yang tidak dapat dipisahkan dari percobaan berikutnya.

Perkembangan teori ini diawali oleh percobaan yang dilakukan oleh kohler terhadap seekor simpanzee (sejenis kera berwara hitam) disebuah lembaga konservasi satwa di pulau Tenerive ke pulau Canaries. Simpanzee yang lebih dahulu dilaparkan di tempat dalam sangkar berjeruji besi dan diluarnya diletakkan pisang. Di dekat pisang tersebut diletakkan sepotong tongkat dan dengan tongkat itu ia bisa meraih pisang. Experiment ini bertujuan untuk menyelidiki apakah hewan itu mampu melihat hubungan arti antara tongkat dan pisang itu. Tanpa melalui proses trail and error. Secara tiba-tiba hewan tersebut. Melihat hubungan arti tongkat-pisang dan langsung pisang diraih dengan tongkat tersebut. Dipercobaan lain keadaanya semakin dipersulit namun masih tetap berhasil, kecuali beberapa di antaranya yang situasinya lebih rumit. ${ }^{13}$

Percobaan itu Kohler berkesimpulan bahwa proses belajar terjadi bukan hasil trail and error atau pengaturan stimulus-stimulus, tetapi belajar berlangsung dari hasil kemampuan menganalisis situasi yang dihadapi berujud suatu kebulatan yang penuh arti hingga mengetahui serta memahami. Semakin jelas makna atau arti dalam situasi semakin mudah dan cepat berlangsungnya proses belajar. Dari percobaan inilah disimpulkan bahwa belajar adalah hasil kemampuan kognitif (kecerdasan, pemahaman, pengertian dll), dan bukan hasil mekanisme dari respon atau stimulus, lalau teori kognitif ini mencapai puncaknya pada Bruner. Yang pada konsep ini lebih dikenal dengan sebutan Instrumental Conceptualisme yang dipelopori oleh Jerome S. Bruner yang awalmulanya belajar adalah bukan terjadi karena rangsangan luar (S), tatapi situasi yang dihadapi mengandung pengertian/konsep, prinsip dan kaidah yang khas dan padat. Situasi yang demikian biasanya cenderung seseorang untuk memahami, menemukan prinsip, menyimpulkan serta mencobanya. ${ }^{14}$

Percobaan di atas terlihat bahawa Bruner hanya kognitivisme yang mengambil hasil percobaan orang lain untuk memperkuat teori yang ada. Walau ia hanya sekedar memperkuat atau mengambil hasil orang lain namun ia berhasil memberikan pemahaman yang mendalam tentang belajar kognitif melalaui teorinya yang lebih dikenal sebagai belajar discovery (belajar penemuan).

13 Ramly Mahala, Psikologi...,hal.34

14 Ibid. hal. 36 


\section{c. Prinsisp teori belajar discovery menurut Jerome Bruner.}

Sebagai psikolog Bruner lebih memperhatikan perkembangan kemampuan mental. Berkaitan masalah pengajaran, ia mengemukakan dalil tentang intruksi. Ada dua sifat dalam teori intruksi yaitu preskriptif dan normative. Preskriptif berhubungan dengan mekanisme penguasaan pengetahuan, keterampilan dan tekhnik pengukuran atau evaluasi hasil. Sedangkan normative berhubungan dengan penguasaan penentuan dan kondisi tujuan. Untuk itu dalam proses belajar discovery memiliki prisnsip-psinsip sebagai berikut:

1. Semakain tinggi tingkat perkembangan intelektual seseorang, makin meningkat pula ketidak tergantungan individu terhadap stimulus yang diberikan.

2. Pertumbuhan seseorang tergantung pada perkembangan kemampuan internal untuk menyimpan dan memproses informasi. Data yang diterima orang dari luar perlu diolah secara mental.

3. Perkembangan intelektual meliputi peningkatan kemampuan untuk mengutarakan pendapat dan gagasan melalui simbol.

4. Untuk mengembangkan kognitif seseorang diperlukan interaksi yang sistematik antara pengajar dan yang peserta didik.

5. Perkembangan kognitif meningkatkan kemampuan seseorang untuk memikirkan beberapa alternative secara serentak, memberikan perhatian kepada beberapa stimulus dan situasi serta melakukan kegiatan-kegiatan. ${ }^{15}$

Prinsip-prinsip di atas dapat terlihat jelas bahwa teori discovery atau belajar penemuan sangat memberi perhatian tinggi terhadap perkembangan kognitif peserta didik. Baik secara teori mupun apilikasi yang hendak dikerjakan di dalam kelas atau lingkungan.

\section{d. Kelebihan dan kelemahan teori belajar discovery dalam pembelajaran}

Teori adalah hasil kesimpulan yang ditemukan secara ilmiah. Ilmiah artinya dapat berlaku dalam waktu tertentu sampai ada pembaharuan atau hasil penemuan yang baru dan teruji kebenarannya secara ilmiah pula. Teori yang dihasilkan juga tentu ada sisi kelebihan dan kelemahan tersendiri. Berikut kelebihan atau keunggulan pengetahuan yang diperoleh dengan belajar discovery atau penemuan menunjukkan adalah sebagai berikut:

15 Abdul halamid, Teori Belajar...,hal. 24 
- Pengetahuan itu akan bertahan lebih lama atau lama dapat diingat, mudah diingat, bila dibandingkan dengan pengetahuan yang dipelajari dengan caracara yang lain.

- Sebagian itu belajar penemuan memiliki hasil belajar yang mempunyai efek transfer yang lebih baik dari hasil belajar lainnya. Artinya konsep-konsep yang ditemukan menjadi milik kognitif seseorang lebih mudah diterapkan pada situasi baru atau pada saat dibutuhkan.

- Disisi lainnya secara menyeluruh belajar penemuan dapat meningkatkan penalaran belajar suatu topik, meningkatkan kemampuan untuk berpikir secara bebas dan sistimatis. Khususnya lagi belajar penemuan mampu melatih keterampilan kognitif pelajar untuk menemukan dan memecahkan masalah tanpa pertolongan orang lain. ${ }^{16}$

Pendapat lain juga dikemukan bahwa belajar penemuan akan memberikan keleluasaan siswa dalam memecahkan masalah di bidangnya. Membiarkan siswa memecahkan masalah dan menentukan makna memungkinkan mereka belajar konsep dengan bahasa yang diketahui dan melalui modus representasi yang dimiliki keuntungan belajar penemuan menurut Bruner adalah: Ada nilai tambah dalam potensi intelektual, tekanan terletak pada hadiah instrinsik, siswa belajar menemukan sesuatu, memungkinkan siswa mengingat informasi ${ }^{17}$

Bruner menyadari bahwa belajar penemuan yang murni memerlukan waktu. Karena itu, dalam bukunya the relevance of education (1971) ia menyarankan agar penggunaan belajar penemuan ini hanya diterapkan sampai batas-batas tertentu, yaitu dengan mengarahkan pada struktur bidang studi.

Struktur suatu bidang studi terutama diberikan oleh konsep-konsep dasar dan prinsip-prinsip dari bidang studi. Bila seorang siswa telah menguasasi struktur atas dasar maka tidak sulit baginya untuk mempelajari bahan-bahan pelajaran lain dalam bidang studi yang sama, dan ia akan lebih mudah ingat akan bahan baru itu, hal ini disebabkan karena ia telah memperoleh kerangka pengetahuan yang esensial dalam bidang studi ini dan dengan demikian dapat memahami hal-hal yang mendetail. ${ }^{18}$ Ini menunjukkan bahwa selain teori ini memiliki sisi keunggulan tersendiri ia juga memiliki kekurangan dari analisis penulis dari paparan di atas sebagai berikut:

16 Ibid. hal. 25

17 Nurhalayati, Teori Belajar...,hal. 33

18 Adbul HALamid, Teori Belajar...,hal. 26 
- Dari sekian bidang studi yang ada tidak semua bidang studi atau sub judul bidang studi dapat dilakukan dengan teori belajar penemuan.

- Tidak semua peserta didik mampu diajak kerja sama melakukan proses berpikir sebagaimana yang diharapkan.

- Sulitnya teori ini diterapan pada budaya masyarakat yang berlainan antara satu daerah dengan daerah yang lain.

- Teori ini relative sulit karena akan memakan waktu yang relative lama, dikarenakan siswa kurang terbiasa untuk melakukan proses berpikir individu juga kelompok.

\section{e. Implikasi teori belajar discovery dalam proses pembelajaran}

Teori belajar discovery yang dihasilkan oleh Bruner dapat memberikan masukan yang sangat besar bagi perkembangan ranah kognitif siswa. Ranah kognitif siswa memilki ketergantungan terhadap informasi yang diperoleh melalui proses yang dijalaninya, semakin banyak informasi yang diserap lalu mampu dianalisa dengan baik, maka semakin besar pula ranah kognitif yang ditemukan, sebaliknya semakin kecil ruang lingkup informasi yang ditemukan maka sungguh semakin kecil kemungkinan ranah kognitif ini berproses pada diri seseorang (peserta didik). Secara garis besar proses pengembangan ranah kognitif seseorang dapat diperoleh melalui banyak strategi, baik secara drill, pemecahan masalah, penugasan sampai pada strategi inkuiri. Walau staregi inkuiri dikatakan berbeda pada inti tujuannya, namun menurut penulis strategi inkuiri adalah salah satu cara untuk memperkaya dan memenuhi perkembangan kognitif seseorang.

Zaman yang semakin canggih dewasa ini memberikan peluang yang luas untuk pengembangan ranah kognitif tersebut, selain alat teknologi yang telah mendunia, dari wilayah ibu kota, masyarakat menengah hingga masyarakat pesisir telah dapat diakses kapanpun mereka inginkan. Tinggal lagi kemampuan, motivasi serta pemberdayaan alat tersebut mampu atau tidak digunakan sesuai dengan tujuan dan manfaat dari yang sesungguhnya. Bagai teori Bruner misalkan, jika siswa ingin lebih terbuka untuk mencari melalui dunia maya sah-sah saja, atau melalui bertanya kepada siapa yang lebih tahu, dan dapat pula dicari melalui buku-buku klasik (pustaka) untuk memperkaya pengetahuannya dahulu hingga perkembangan dunia sekarang. Hal ini sesuai dengan apa yang disampaikan oleh Bruner tentang pembelajaran sains misalkan, kita bukan akan menghasilkan perpustakaanperpustakaan hidup kecil tentang sains, malainkan kita ingin membuat anak-anak 
kita berpikir secara matematika bagi dirinya sindiri, berperan serta dalam proses perolehan pengetahuan. Pengetahuan itu adalah proses bukan suatu produk yang lahir begitu saja dari diri seseorang. ${ }^{19}$

Ungkapan di atas bertujuan untuk menjelaskan tujuan-tujuan mengajar hanya dapat diuraikan secar garis besar, dan dapat dicapai dengan cara-cara yang tidak perlu sama oleh para siswa yang mengikuti pelajaran yang sama. Terlihat jelas dari proses belajar discovery Bruner memberikan kebebasan sampai batas-batas tertentu untuk menyelidiki, secara perorangan atau kelompok, dalam suatu Tanya jawab dengan guru, atau oleh guru, atau oleh siswa-siswa lain untuk memecahkan masalah yang diberikan oleh guru. Dengan demikian proses belajar discovery jelas, bahwa peranan guru lain sekali bila dibandingkan dengan peranan guru yang mengajar secara klasikal dengan metode ceramah. Dalam proses belajar ini guru tidak begitu mengendalikan proses belajar mengajar. Hal ini dapat terlihat dari peranan seorang guru dalam belajar discovery berikut:

1. Merencanakan pelajaran sedemikian rupa sehingga pelajaran itu berpusat pada masalah-masalah yang tepat untuk diketahui oleh siswa, baik secara kelompok maupun secara individu.

2. Menyajikan materi pelajaran yang diperlukan sebagai dasar bagi para siswa untuk memecahkan masalah. Berupa:
a. Menggunakan fakta-fakta yang belawanan.
b. Menggunakan hal yang sudah dikenali oleh siswa.
c. Siswa akan merasa sanggsi dengan jawab sehigga lahirlah hipotesis siswa.
d. Menemukan konsep atau teori dari masalah yang sesungghnya.

3. Memperhatikan tiga hal, berupa cara enaktik (berifat manupulatif), ikonik (bersifat latar belakang kemampuan internal siswa), dan cara simbolik (berdasarkan media berpikir).

4. Jika dilakukan di Labolatorium, maka guru adalah sebagai pembimbing (tutor) atau fasilitator siswa.

5. Menilai hasil belajar, setelah adanya proses penarikan kesimpulan dari guru secara keseluruhan. Memberikan motivasi kepada siswa untuk terus mencari dan berpikir terhadap materi-materi yang dipandang belum diketahui. Meberi penghargaan yang berhasil dan memutivasi bagi yang kurang beruntung. 


\section{Penutup}

Pembahasan terhadap teori Bruner dapat disimpulkan sebagai berikut:

Teori belajar Discovery menurut Bruner adalah proses memperoleh informasi baru, transformasi informasi, dan menguji relevansi dan ketepatan pengetahuan, teori belajar penemuan yang ditemukan oleh Bruner adalah memahami konsep, arti, dan hubungan melalui proses intuitif (yang disesuiakan dengan kemampuan masing-masing) untuk akhirnya sampai kepada sesuatu kesimpulan yang disebut dengan istilah discovery learning. Bruner tidak secara langsung malakukan uji coba experiment terhadap hewan atau manusia, ia hanya mengembangakan dari percobaan yang dilakukan oleh Kohler terhadap seekor simpanzee (sejenis kera berwara hitam) disebuah lembaga konservasi satwa di pulau Tenerive kepulaan Canaries. Simpanzee yang lebih dahulu dilaparkan di tempat dalam sangkar berjeruji besi dan diluarnya diletakkan pisang. Di dekat pisang tersebut diletakkan sepotong tongkat dan dengan tongkat itu ia bisa meraih pisang. Dari percobaan inilah disimpulkan bahwa belajar adalah hasil kemampuan kognitif (kecerdasan, pemahaman, pengertian dll), dan bukan hasil mekanisme dari respon atau stimulus, lalu teori kognitif ini mencapai puncaknya pada Bruner. Yang pada konsep ini lebih dikenal dengan sebutan Instrumental Conceptualisme yang dipelopori oleh Jerome S. Bruner yang awalmulanya belajar adalah bukan terjadi karena rangsangan luar (S), tatapi situasi yang dihadapi mengandung pengertian/konsep, prinsip dan kaidah yang khas dan padat. Dimana situasi yang demikian biasanya cenderung seseorang untuk memahami, menemukan prinsip, menyimpulkan serta mencobanya.

Prinsip-prinsip yang dimiliki oleh teori ini diantaranya semakin tinggi tingkat perkembangan intelektual seseorang, Pertumbuhan seseorang tergantung pada perkembangan kemampuan internal untuk menyimpan dan memproses informasi, Perkembangan intelektual meliputi peningkatan kemampuan untuk mengutarakan pendapat dan gagasan melalui simbol, mengembangkan kognitif seseorang diperlukan interaksi yang sistematik antara pengajar dan peserta didik, dan perkembangan kognitif meningkatkan kemampuan seseorang untuk memikirkan beberapa alternative secara serentak, memberikan perhatian kepada beberapa stimulus dan situasi serta melakukan kegiatan-kegiatan.

Kelebihan dari teori ini adalah Pengetahuan itu akan bertahan lebih lama atau lama dapat diingat, mudah diingat, Selain itu belajar penemuan memiliki hasil belajar yang mempunyai efek transfer yang lebih baik dari hasil belajar lainnya, dan disisi lainnya secara menyeluruh belajar penemuan dapat meningkatkan 
penalaran belajar suatu topik, meningkatkan kemampuan untuk berpikir secara bebas dan sistematis. Sedangkan kelemahannya adalah dari sekian bidang studi yang ada tidak semua bidang studi atau sub judul bidang studi dapat dilakukan dengan teori belajar penemuan, sedangkan kelemahannya adalah tidak semua peserta didik mampu diajak kerja sama melakukan proses berpikir sebagaimana yang diharapkan, sulitnya teori ini diterapkan pada budaya masyarakat yang berlainan antara satu daerah dengan daerah yang lain, Teori ini relative sulit karena akan memakan waktu yang relative lama, dikarenakan siswa kurang terbiasa untuk melakukan proses berpikir individu juga kelompok

\section{DAFTAR PUSTAKA}

Hamid, Abdul, 2007, Teori Belajar dan Pembelajaran Buku Edisi I, Program Pascasarjana Universitas Negeri Medan

—, Teori Belajar dan Pembelajaran Buku Edisi II, tidak diterbitkan

Habullah, 2008, Dasar-dasar Ilmu Pendidikan Jakarta: Raja Grapindo Persada

Hafifuddin dan Zulfikar, 2007, Ilmu Pendidikan Diktat Ilmu Pendidikan STAIN Malikussaleh Lhokseumawe

http://www.answers.com/topic/jerome-bruner

http://www.psych.nyu.edu/people/faculty/bruner

Malik, Oemar, 2006, ProsesBelajar Mengajar Jakarta: Bumi Aksara

Nurhayati, 2009, Teori Belar dan Pembelajaran Diktat: STAIN Malikussaleh Lhokseumawe

Ramly Maha, 2002, Psikologi Pendidikan Banda Aceh: Selamat Sejahtera

Ratna Wilis Dahar, 1989, Teori-teori Belajar Jakarta: Erlangga

Riyanto,Yatim, 2009, Paradigma Pembelajaran, Jakarta: Kencana Prenada Media Group. 
